\title{
Prospective study of symptoms and signs in acutely ill infants in general practice
}

\author{
A WRIGHT, G H LUFFINGHAM, D NORTH
}

\begin{abstract}
A study was made of all cases of acute illness in infants aged 6 months or less presenting in a Gosport practice over five months. The frequency in these patients of the well defined symptoms and signs suggested to be important by the preliminary report of the Department of Health and Social Security's multicentre study of postneonatal mortality was recorded. During the study period there were 161 infants of this age in the practice, who gave rise to 69 consultations with acute illness. Thirty eight of these were given drug treatment and five were referred to a paediatric unit, one of them on social grounds. There were no infant deaths in the practice (total population 11400), but two occurred in the Gosport area (total population 83000 ).

It would be unrealistic to refer all patients with any one of the symptoms and signs, even when well defined, in the age group 6 months or less. Analysis of the symptoms and signs found in those children who required admission did not show any pattern differentiating them from those who did not. Although the symptoms and signs studied are of value in assessment and should be sought in these patients, they cannot be used singly or in any pattern to indicate referral per se.
\end{abstract}

\section{Introduction}

In 1978 a preliminary report of the Department of Health and Social Security's multicentre study of postneonatal mortality noted 18

Quarry Ground Surgery, Edington, Bridgwater, Somerset A WRIGHT, MRCP, MRCGP, general practitioner

Gosport, Hampshire

G H LUFFINGHAM, MRCGP, general practitioner

D NORTH, DCH, MRCGP, general practitioner

Correspondence to: Dr Wright. symptoms that were common in infants who suffered sudden unexpected death. ' The finished study suggested that infants aged 6 months or less ran the highest risk. ${ }^{2}$ When general practitioners had been consulted about infants with symptoms who subsequently died suddenly the study considered that inappropriate action had been taken in $64 \%$ of cases. In $26 \%$ of cases where infants had been referred to hospital, inappropriate action was considered to have been taken by the admitting paediatricians. A controversial leading article in the British Medical fournal subsequently attempted to highlight the most sinister of these symptoms and recommended that their presence in infants aged 6 months or less should lead to referral to a paediatric unit. ${ }^{3}$ Two studies of these symptoms in the age group 12 months or less have been published with strikingly different results. ${ }^{45}$ Neither attempted to define the symptoms and signs under review. This study records the incidence of symptoms and signs highlighted previously, strictly in the context of consultation for acute illness in the age group of 6 months or less. The symptoms and signs were strictly defined and then studied to see whether they themselves, or any pattern of them, might indicate referral.

\section{Method}

This was a prospective study conducted in a practice with five full time principals and one trainee, providing care for patients at all times. A full history was taken and examination performed on all unwell infants aged 6 months or less consulting for the first time with an illness. They were then registered on an encounter sheet and any of the defined symptoms and signs were noted. This took place both in the surgery and at home visits. Table I shows the symptoms and signs recorded together with their definitions. Some were elicited by a careful history alone while others required confirmatory examination. Weight charts were kept, recordings being made at one or two week intervals on the same set of scales by the practice health visitor. Treatment given, diagnosis when possible, any potentially serious physical findings, and hospital admission were all recorded on the encounter sheet. All patients were followed up at two weeks irrespective of the course of their illness. The study was conducted for five months. The symptoms and signs defined were not sought in the context of consultations for unrelated issues such as vaccination. 


\section{Results}

A total of 69 initial consultations were recorded at which an unwell infant presented with acute illness and one or more symptoms or signs were elicited. The monthly pattern of initial visits was 14 in September (no referrals); 11 in October (two); 13 in November (one); 20 in December (two); and 11 in January (none). Most patients seen had more than one symptom or sign: the total number was 196 (average 2.84 per patient). Noisy breathing due to upper respiratory tract infection was seen in 51 infants, noisy breathing not due to upper respiratory tract infection in 20 , a change in feeding pattern in 38 , a change in bowel habit in 20 , drowsiness in 16, fast breathing in 10 , altered cry in 15 , and irritability in 26 . Table II gives details of the five infants admitted, their symptoms, and general practitioner and hospital diagnoses. One child was admitted on social grounds. The diagnoses reached by the general practitioner were: viral upper respiratory tract infection, 41 infants; bronchiolitis, four; viral gastroenteritis, 14; and pertussis, two. The drugs given to the infants by the general practitioner were: nasal ephedrine, 15 patients; phenoxymethylpenicillin, five; amoxycillin, four; inhalations, six; nystatin (for oral thrush), four; paracetamol (as Calpol), seven; and electrolyte replacement (Dioralyte), three.

No infants who were seen but not admitted exhibited physical signs that were serious in themselves, such as bradycardia, appreciable airflow limitation, unrousability, or $\geqslant 5 \%$ dehydration; nor did they have a history (given by the mother) characteristic of apnoea, epilepsy, or other such serious disturbance. One of the patients admitted had appreciable airflow limitation, two had appreciable dehydration, and only one had a history of possible apnoea. None of the patients admitted had any of the other signs above or any history suggestive of epilepsy.

Adequate weight charts were available for 60 of the 69 patients, and these indicated that 15 infants experienced a drop in weight during the study period, one in the week before consultation though none in the week before admission. Eight records showed a failure of the weight to rise in the week before consultation and one in the week before admission. There were no unexpected infant deaths. Follow up at two weeks found no patient still suffering defined symptoms or signs. All of the infants seen because of acute illness had at least one of the defined symptoms and signs.

\section{Discussion}

The final report of the Department of Health and Social Security's multicentre study concluded that when sudden deaths in previously fit infants had been preceded by consultation with the general

TABLE I-Symptoms and signs studied and their definitions

\begin{tabular}{ll}
\hline Symptom or sign & \multicolumn{1}{c}{ How defined } \\
\hline $\begin{array}{l}\text { Noisy breathing due to upper } \\
\text { respiratory tract infection } \\
\begin{array}{l}\text { Noisy breathing not due to upper } \\
\text { respiratory tract infection }\end{array}\end{array}$ & $\begin{array}{l}\text { Cause of symptoms defined by examining } \\
\text { doctor } \\
\text { Taking } \leqslant 50 \% \text { of normal feed, taking over twice } \\
\text { normal time to feed, refusal to feed, vomiting } \\
\text { Increased frequency or looseness of stool, or both } \\
\text { Change in behaviour with increased tendency to } \\
\text { fall asleep } \\
\text { Change in bowel habit } \\
\text { Drowsiness }\end{array}$ \\
$\begin{array}{l}\text { Change in pitch, strength, or character of cry } \\
\text { Pronounced change in behaviour with excessive } \\
\text { Altered cry } \\
\text { Irritability }\end{array}$ & \begin{tabular}{l} 
crying related or unrelated to interactions \\
\hline
\end{tabular} \\
\hline
\end{tabular}

TABLE II-Symptoms and diagnosis in patients admitted

\begin{tabular}{|c|c|c|c|c|}
\hline Age & Sex & Symptoms or signs & Reason for referral & Hospital diagnosis \\
\hline 3 Weeks & $\mathbf{M}$ & $\begin{array}{l}\text { Change in feeding pattern, } \\
\text { change in bowel habit }\end{array}$ & Feeding problem & $\begin{array}{l}\text { Feeding problem, after } \\
\text { gastroenteritis }\end{array}$ \\
\hline 2 Months & $\mathbf{M}$ & $\begin{array}{l}\text { Change in feeding pattern, } \\
\text { change in bowel habit }\end{array}$ & Limp episode & Cows' milk allergy \\
\hline 6 Weeks & $\mathbf{F}$ & $\begin{array}{l}\text { Noisy breathing not due to } \\
\text { upper respiratory tract } \\
\text { infection, fast breathing, } \\
\text { change in feeding pattern }\end{array}$ & ? Pertussis & $\begin{array}{l}\text { Chest infection with } \\
\text { respiratory syncytial } \\
\text { virus }\end{array}$ \\
\hline 3 Months & $\mathbf{M}$ & Change in bowel habit & $\begin{array}{l}\text { Mother in hospital, } \\
\text { father not coping }\end{array}$ & $\begin{array}{l}\text { Cryptosporidium } \\
\text { diarrhoea }\end{array}$ \\
\hline 6 Weeks & $\mathbf{M}$ & $\begin{array}{l}\text { Noisy breathing due to } \\
\text { upper respiratory tract } \\
\text { infection, change in } \\
\text { feeding pattern, } \\
\text { irritability, fast breathing }\end{array}$ & Clinical pertussis & Pertussis \\
\hline
\end{tabular}

practitioner inappropriate management had been instigated in two thirds of the cases. ${ }^{2}$ This conclusion together with research into symptomatology led to recommendations as to possible improvements in management by general practitioners when dealing with infants with suspected acute illness. Because of the emotional and possible medicolegal difficulties that may follow infant death the idea of a proposed list of symptoms and signs facilitating management is attractive. We reviewed the possibility that recommended well defined symptoms and signs, used singly or together with a scoring system, that would indicate referral would simplify the management of acute illness in infants aged 6 months or less who presented to their general practitioner. From the figures here, however, it would seem that referral of all patients with one or more symptom or sign would increase the admission rate to an extent that would be difficult to justify. The patients whom both the referring general practitioner and the admitting doctor agreed required admission were not characterised by an excessive number of symptoms or signs (average 2.84 overall; average 3.0 in those admitted (after exclusion of the social admission)). The only symptom common to those admitted was "change in feeding pattern," which was seen in 34 of those patients not admitted. Poor feeding was the commonest symptom discovered in the study of Thurtle $e t a l$, conducted by 18 doctors over two weeks in the age group under 12 months. ${ }^{4}$ No attempt to define symptoms or signs was made in this study, and their rate of symptoms and signs was considerably higher than ours. They suggested that the presence of more than one symptom or sign might be of predictive value in management but gave no data to support this. In their study all children seen in the surgery were quizzed on symptoms. In our study a further 160 consultations in the age group of 6 months or younger would have occurred in the five month period for a six week check and first immunisation together with further consultations for such problems as napkin rash. Symptoms might possibly have been elicited then if sought.

Wilson et al performed a retrospective study of acute illness in infants of 12 months and less and found a rate of consultation and symptoms similar to ours, although again their terms were undefined..$^{5}$ In their study no patients were admitted to hospital. Their conclusion was that, undefined, the symptoms studied were too common to help management of unwell infants in general practice.

Although weight loss was a common symptom described by parents, the objective measurements did not confirm its presence. Analysis of weight charts showed that objective weight loss occurred on 15 occasions among the 60 patients for whom data were available for analysis. In only one infant did this occur in the week before consultation, and this patient was adequately managed without admission to hospital. In eight cases failure of weight gain was seen in the week before consultation and one of these patients required admission.

From this study we believe the symptoms and signs defined to be of value in assessing sick infants. We do not believe, however, that they can be used alone or together to take the place of multifactorial clinical judgment or paediatric experience in deciding referral to hospital.

We acknowledge the work of Drs B Coonan, D N Lynch, E O'Callaghan, and $\mathrm{P} J$ Old, without whom this study would not have been possible. We also thank Karen Passmore for typing the manuscript and Iris Joly for providing weight data.

\section{References \\ 1 Stanton AN, Downham MAPS, Oakley JR, Emery JL, Knowelden J. Terminal symptoms in children dying suddenly and unexpectedly at home: preliminary report of the DHSS multicentre children dying suddenly and unexpectedly at home: preliming \\ 2 Knowelden J, Keeling J, Nicholl JP. A multi-centre study of post-neonatal mortality. London: Department of Health and Social Security, 1985. \\ 3 Valman B. Preventing infant deaths. Br Med f 1985;290:339. \\ 4 Thurtle OA, Cox P, Fall C, et al. Preventing infant deaths. Br Med f 1985;290: 1434-5. \\ Wilson AD, Downham MAPS, Forster DP. Acute illness in infants: a general practice study. $\mathcal{F} R$ Coll Gen Pract 1984;34:155-9.}

(Accepted 5 fune 1987) 